\title{
MIDNIGHT WELFARE SEARCHES AND THE SOCIAL SECURITY ACT
}

\author{
CHARLES A. REICH广்
}

IN many states, and in the District of Columbia, it has become common practice for authorities to make unannounced inspections of the homes of persons receiving public assistance. Often such searches are made without warrants and in the middle of the night. The purpose of the inspections is to check on recipients' eligibility for assistance. Eligibility, under state or local law, may be determined by many aspects of a family's circumstances, including the presence or absence of an adult man capable of supporting the family. The searches are sometimes based upon particular evidence known to investigators beforehand, but on occasion there have been mass raids designed as general checks on eligibility. The demand for entry may carry with it the threat, express or implied, that refusal to admit will lead to discontinuance of public assistance.

Under the Social Security Act, ${ }^{1}$ the federal government participates to a substantial degree in state public assistance programs. The Act sets forth detailed requirements that state plans must meet to qualify for payment of federal funds and provides for approval of state plans by the Secretary of Health, Education and Welfare. ${ }^{2}$ Nothing in the Act deals explicitly with the matter of searches. But the widespread use of midnight searches in the administration of welfare programs which are federally supported nevertheless presents a problem of national concern. This concern must be all the greater because persons on welfare are mostly unable to protect their own rights, and because the searches have become an integral part of an otherwise beneficent program that is central to the welfare state.

\section{Welfare Searches and the Constitution}

The first question that must be asked is whether midnight inspections are consistent with the federal Constitution. The fourth amendment provides:

The right of the people to be secure in their persons, houses, papers and effects, against unreasonable searches and seizures, shall not be violated, and no Warrants shall issue, but upon probable cause, supported by Oath or affirmation, and particularly describing the place to be searched, and the persons or things to be seized.

The rights guaranteed by this amendment are enforceable against the federal government and, through the due process clause of the fourteenth amendment, against the states. ${ }^{3}$

†Associate Professor of Law, Yale University. This article is based on a memorandum prepared for the Field Foundation.

1. 49 Stat. 620 (1935), as amended, 42 U.S.C. $\$ \$ 301-1371$ (1958).

2. See, e.g., 49 Stat. 627, 629, 631 (1935), as amended, 42 U.S.C. $\$ \S 601-02,701-03$, 711-13 (1958).

3. Mapp v. Ohio, 367 U.S. 643 (1961) ; Elkins v. United States, 364 U.S. 206 (1960); Wolf v. Colorado, 338 U.S. 25 (1949). 
Do searches of welfare recipients' homes without warrants violate the fourth and fourteenth amendments? They might be justified, if at all, only by one of these general arguments: (a) that the searches are conducted with the consent, express or implied, of the recipients; (b) that the object of the searches is not to secure evidence for criminal prosecution or forfeiture; (c) that the searches, under all the circumstances, are reasonable. These issues will be discussed below.

\section{A. Consent}

An entry or search that might appear to be a violation of constitutional rights may be validated by consent, express or implied. Welfare inspectors do not force their way in; they enter only when the occupant opens the door. Our first problem is whether this form of acquiescence in a search constitutes "consent."

Two leading decisions of the Supreme Court deal with the question of acquiescence to a search. In Johnson $v$. United States, ${ }^{4}$ the occupant of a room opened the door after the police knocked and said they wanted to talk to her. The Court held that the occupant had not freely consented to the officers' entry and subsequent search:

Entry to defendant's living quarters, which was the beginning of the search, was demanded under color of office. It was granted in submission to authority rather than as an understanding and intentional waiver of a constitutional right. 5

In Amos v. United States, ${ }^{6}$ officers went to a home and told the woman who answered the door that they were revenue officers come to search the premises, whereupon she admitted them. The Court ruled:

The contention that the constitutional rights of defendant were waived when his wife admitted to his home the Government officers, who came, without warrant, demanding admission to make search of it under Government authority, cannot be entertained. We need not consider whether it is possible for a wife, in the absence of her husband, thus to waive his constitutional rights, for it is perfectly clear that under the implied coercion here presented, no such waiver was intended or effected. ${ }^{7}$

Thus the mere demand for admission by one in authority is likely to be considered as coercive. ${ }^{8}$ The courts are quick to note the "disparity of position" between a government agent and a "humble" ordinary citizen. ${ }^{\circ}$ In light of these

4. 333 U.S. 10 (1948):

5. Id. at 13 .

6. 225 U.S. 313 (1921).

7. Id. at 317 .

8. Judd v. United States, 190 F.2d 649, 650-51 (D.C. Cir. 1951).

9. Canida v. United States, 250 F.2d 822, 825 (5th Cir. 1958). See also Nelson v. United States, 208 F.2d 505 (D.C. Cir. 1953), cert. denicd, 346 U.S. 827 (1953) ; Ray v. Unitcd States, 84 F.2d 654, 656 (5th Cir. 1936). 
cases, it seems clear that the opening of a door by a welfare recipient, in response to a demand by official investigators, is not consent to a search. ${ }^{10}$

The conclusion that consent is not present in a typical welfare search has been reached without assuming the existence of any pressure on the occupants other than that generated by the mere presence of authority. In reality, there is often a threat, sometimes made explicitly, and sometimes merely present in the mind of the recipient, that unless inspectors are admitted public assistance will be taken away. This fact greatly strengthens the conclusion that there is no freely given consent. In a recent case involving a coerced confession, the Supreme Court held that the threat that "state financial aid for her infant children would be cut off ..." constituted an important element of coercion."1 This case leaves little doubt that the Court would deem even an implied threat to cut off assistance as coercive in a welfare search situation.

If there is no voluntary consent, is there any ground for contending that recipients of public assistance impliedly consent to inspections when they accept assistance? The Supreme Court has held that in special circumstances, where a citizen is required by law to keep certain records, the citizen may be held to have accepted the obligation to permit them to be inspected. ${ }^{12}$ However, the theory of such cases is that the citizen has in his possession property that does not belong to him-property that is public, not private. Welfare recipients are not required to keep any comparable records, and there is nothing else in their

10. The status of the law on this point has been well summarized by Judge Washington of the Court of Appeals for the District of Columbia:

Searches and seizures made without a proper warrant are generally to be regarded as unreasonable and violative of the Fourth Amendment. True, the obtaining of the warrant may on occasion be waived by the individual; he may give his consent to the search and seizure. But such a waiver or consent must be proved by clear and positive testimony, and it must be established that there was no duress or coercion, actual or implied. Amos v. United States, 255 U.S. 313, 41. S. Ct. 266, 65 L. Ed. 654 ; United States v. Kelih, D.C.S.D. Ill. 1921, 272 F. 484. The Government must show a consent that is "unequivocal and specific" (Karwicki v. United States, $4 \mathrm{Cir} .55$ F.2d 225, 226), "freely and intelligently given." Kovach v. United States, 6 Cir., 53 F.2d 639. Thus "invitations" to enter one's house, extended to armed officers of the law who demand entrance, are usually to be considered as invitations secured by force. United States v. Marquette, D.C.N.D. Cal. 1920, 271 F. 120. A like view has been taken where an officer displays his badge and declares that he has come to make a search (United States v. Slusser, D.C.S.D. Ohio 1921, 270 F. 818), even where the householder replies "All right" United States v. Marra, D.C.W.D.N.Y. 1930, 40 F.2d 271. A finding of consent in such circumstances has been held to be "unfounded in reason." Herter v. United States, 9 Cir., 27 F.2d 521. Intimidation and duress are almost necessarily implicit in such situations; if the Government alleges their absence, it has the burden of convincing the court that they are in fact absent.

Judd v. United States, 190 F.2d 649, 650-51 (D.C. Cir. 1951).

11. Lynumn v. Illinois, 372 U.S. 528, 534 (1963).

12. Shapiro v. United States, 335 U.S. 1, $32-35$ (1948) ; Davis v. United States, 323 U.S. 582, 587-91 (1946) ; Wilson v. United States, 221 U.S. 361 (1911). See also Bowles v. Glick Bros. Lumber Co., 146 F.2d 566 (9th Cir. 1945), cert. denied, 325 U.S. 842 1945; Rodgers v. United States, 138 F.2d 992 (6th Cir. 1943). 
homes that could possibly be deemed public property justifying an inspection. Even under the public records doctrine inspection must be carried on in a reasonable manner. The Supreme Court, in upholding inspection of public records held by a private individual, stressed that the inspection took place at "a place of business, not a private residence," and that it occurred "during business hours." 13 The Court added :

We do not suggest that officers seeking to reclaim government property may proceed lawlessly and subject to no restraints. Nor do we suggest that the right to inspect under the regulations subjects a dealer to a getneral search of his papers for the purpose of learning whether he has any coupons subject to inspection and seizure. ${ }^{14}$

In summary, there is no theory under which it can be said that public as sistance recipients consent, expressly or impliedly, to searches of their homes. The official demand for entrance is sufficient to render any apparent consent involuntary and the threat of loss of public assistance underscores the coercive nature of the demand for entry.

\section{B. The Object of the Search}

Does the object or purpose of a search affect its validity under the fourth amendment? It has been argued that there is a significant difference between a search for evidence of crime and an inspection to check on eligibility for a government benefit.

In Frank v. Maryland, ${ }^{15}$ the Supreme Court had before it a city ordinance authorizing health inspectors to inspect homes for unsanitary conditions without a warrant, and subjecting householders to a fine for refusal to admit an inspector. In a five-to-four decision, the Court upheld the law. Its reasons were as follows: (a) the inspection was solely for remedial health purposes; no evidence for criminal prosecution or forfeiture was sought; (b) under the ordinance, valid grounds for suspicion were required to exist; (c) the inspection was required to be made in the daytime. The Court said: "Here was no midnight knock on the door, but an orderly visit in the middle of the afternoon, with no suggestion that the hour was inconvenient" $;^{10}$ (d) the inspector had no power to force entry; (e) such inspection had a long history. The Court upheld that statute because it touched "at most upon the periphery of the important interests safeguarded by the fourteenth amendment's protection against official intrusion," and because "it is hedged about with safeguards designed to make the least possible demand on the individual occupant, and to cause only the slightest restriction on his claims of privacy."17

This decision is the chief argument in support of permitting some kinds of

13. Davis v. United States, 328 U.S. 582, 592 (1946).

14. Id. at 591 .

15. 359 U.S. 360 (1959).

16. $I d$. at 366 .

17. Id. at 367 . 
"non-criminal" inspections without warrants. ${ }^{18}$ But the carefully guarded language of the opinion indicates that the holding would not be extended to apply to welfare searches. They lack the safeguards that the Court mentioned. Instead, welfare searches are frequently the very "midnight knock on the door" which the Frank case condemned. It would require a significant extension of Frank: to permit the welfare searches.

Rather than being extended, the prospect is that the Frank case will be limited and that judicial protection of privacy will increase. The four dissenting justices in Frank, all of whom are still serving, contended that the inspection violated the fourth and fourteenth amendments despite its noncriminal purpose and its safeguards. They said that no government official can invade a home for any reason unless he has a warrant or an immediate major crisis affords neither time nor opportunity to get a warrant. ${ }^{10}$ Recent decisions of the Court show it to be moving toward a more sweeping, rather than narrower, interpretation of the right of privacy. ${ }^{20}$

The above comparison of welfare inspections with health inspections has assumed that the welfare inspections are not searches for evidence of crime. But this assumption itself must be questioned. The purpose of searching recipients' homes is, as already stated, to check on their eligibility. But under state public assistance laws, misrepresentation of eligibility may generally be prosecuted as a crime. For example, Section 145 of the New York Social Welfare Law makes it a misdemeanor to obtain public assistance to which one is not entitled, and specifies that failure to notify the appropriate welfare official of any receipt of income shall constitute presumptive evidence of deliberate concealment of a material fact. Moreover, under this statute welfare officials must report apparent violations to the district attorney. In Washington, D.C. misrepresentation may also be punished as a crime under Section 32-765 of the District of Columbia Code. In California a false application for aid to a child constitutes the crime of perjury. ${ }^{21}$ In addition, the unlawful taking of welfare payments, based upon misrepresentation of eligibility, has been held to constitute the crime of grand theft. ${ }^{22}$ In New York, it would also constitute grand larceny. ${ }^{23}$ In Pennsylvania it would be cheating by false pretense. ${ }^{24}$

18. In Ohio ex rel. Eaton v. Price, 364 U.S. 263 (1960), the Supreme Court reaffirmed Frank, 4-4, and in the view of the dissenters, applied it to a different factual situation. However, the majority wrote no opinion, indicating that no extension of Frank was intended. Cf. Abel v. United States, 362 U.S. 217 (1960), also involving a "non-criminal" search; but in that case the search was upheld solely on the ground that it was incidental to a lawiul arrest.

19. Frank v. Maryland, 359 U.S. 360, 374. See also District of Columbia v. Little, 178 F.2d 13 (D.C. Cir. 1950), aff'd on other grounds, 339 U.S. 1 (1950), for a strong statement by Judge Prettyman that the fourth amendment applies equally to non-criminal searches.

20. Wong Sum v. United States, 371 U.S. 471 (1963) ; Mfapp v. Ohio, 367 U.S. 643 (1961) ; Silverman v. United States, 365 U.S. 505 (1961).

21. CaL. Welfare \& Instrtutions Code $§ 1550$ (1956).

22. Dawson v. Superior Court, 138 Cal. App. 2d 685, 292 P.2d 574 (1956).

23. People v. Hubbard, 10 App. Div. 2d 735, 199 N.Y.S.2d 206 (1960).

24. Commonwealth v. Thomas, $166 \mathrm{~Pa}$. Super. 214, 70 A.2d 458 (1950). 
Even more significant for the present discussion is the fact that searches by welfare inspectors have actually led to criminal prosecutions under the laws just cited. For example, in People v. Shirley, ${ }^{25}$ defendant, Tressie Neal, received welfare aid for herself and her minor children. She reported to a county social worker that her only income was her welfare payments plus occasional earnings of the children, and that there were no unrelated adults living with the family. The social worker visited her home one day and found a man there, fully clothed but wearing bedroom slippers. Two days later, investigators came to the house at 2:30 A.M. and found the man in bed in defendant's bedroom1. She then admitted that he had been living there for at least six months and that he had contributed to her support. She was found guilty of the crime of grand theft.

In People v. Phipps, ${ }^{26}$ a woman obtained welfare payments for herself and her nine minor children after stating that her husband was absent from home and that she was seeking a divorce. After accumulating considerable evidence that the husband was actually living at home, investigators paid a nocturnal call, described by the court as follows:

Between 2:00 and 3:00 a.m. on January 28, 1959, investigators went to the Phipps home to investigate the truth of reports that Mr. Phipps was frequenting the home of Mrs. Phipps. The call was made at that untusual hour to preclude the anticipated explanation that Mr. Phipps was at the home for the purpose of visiting his children. As the investigators approached the home they encountered Mr. Phipps as he came out the back door. Mrs. Phipps and several of the children were inside the home. Both Mr. and Mrs. Phipps were fully dressed. She stated that Mr. Phipps had spent the evening there and they were still visiting and awaiting the return of a teenaged daughter who had gone out to attend a dance. ${ }^{27}$

Primarily on the basis of a subsequent admission, but also on the basis of the evidence thus obtained, husband and wife were convicted of grand theft.

In Blackmone v. United States, ${ }^{28}$ Elizabeth Blackmone obtained welfare payments after representing that her husband had deserted her. The following excerpts from the court's opinion are relevant:

On the evening of February 7,1958, three investigators of the Department of Public Welfare went to the house occupied by Mrs. Blackmone. Two of them went to the rear of the premises, and after a short wait, they observed a man running from the rear door in his bare feet and shirt sleeves. The investigators asked him where he was going and requested him to go back into the house with them, which, according to the statement of proceedings and evidence, he did "voluntarily." Inside, they found Mrs. Blackmone and the third investigator, who testified that he had been "admitted" to the premises by Mrs. Blackmone. After some discussion, she stated that the man was her husband. Blackmone then said:

25. 55 Cal. 2d 521, 11 Cal. Rptr. 537, 360 P.2d 33 (1961).

26. 191 Cal. App. 2d 448, 12 Cal. Rptr. 681 (Dist. Ct. App. 1961).

27. 191 Cal. App. 2d at 452,12 Cal. Rptr. at 683.

28. 151 A.2d 191 (D.C. Míum. Ct. App. 1959). 
Well, you've got me boys. My name is Blackmone.... I'm here, you can see. I've been here off and on about three years.

While in the house the investigators noticed men's clothing. ${ }^{20}$

Husband and wife were convicted, on the basis of this and other evidence, of the crime of welfare fraud.

Other cases, not themselves involving inspection, show the importance to criminal prosecutions of evidence that might possibly be obtained by searches of recipients' homes. In People v. Bailey, ${ }^{30}$ the court held that where a man lives with the mother of welfare-aided children, the Department of Social Welfare has the right to treat him as if he were the children's stepfather and to compute eligibility by considering his income. The defendant mother was convicted of grand theft. In People v. Ryerson, ${ }^{31}$ a husband and wife were convicted of obtaining welfare money by false pretenses because they represented that they had separated while actually continuing marital relations. In People v. Hubbard, ${ }^{32}$ a charge of grand larceny was based on misrepresentation of marital status to the Department of Welfare. ${ }^{33}$

It should be added that even the narrowest interpretation of the fourth amendment applies it to evidence for forfeitures as well as crimes. ${ }^{34} \mathrm{~A}$ search for evidence to cancel welfare benefits might well be deemed to be a proceeding for forfeiture. ${ }^{35}$ While this term as used in the early search and seizure cases undoubtedly meant the confiscation of private property as a penalty for violation of law, ${ }^{36}$ deprivation of welfare subsistence could be considered the modern equivalent of a forfeiture.

\section{Reasonableness of Search}

The only remaining argument to support welfare searches is the very general one that they can somehow be justified as "reasonable." The Supreme Court has said: " $[I] t$ is only unreasonable searches and seizures which come within the constitutional interdict. The test of reasonableness cannot be stated in rigid and absolute terms. 'Each case is to be decided on its own facts and circumstances. ... ?"

In the two leading cases in which this statement was made, searches without

29. Id. at 194.

30. 55 Cal. 2d 514, 360 P.2d 39, 11 Cal. Rptr. 543 (1961).

31. 199 Cal. App. 2d 646, 19 Cal. Rptr. 22 (Dist. Ct. App. 1962).

32. 10 App. Div. 2d 235, 199 N.Y.S.2d 206 (1960).

33. In addition to evidence of the crimes described above, searches of recipients' homes might furnish evidence of closely related crimes, such as adultery or fornication. Section 405 of the Social Security Act also recognizes that states may impose criminal penalties based upon misuse of funds provided for the benefit of a child. 76 Stat. 188 (1962), 42 U.S.C. $\S 605$ (1962 Supp.).

34. Frank v. Maryland, supra note 16, at 365 .

35. But cf. Flemming v. Nestor, 363 U.S. 603 (1960).

36. Boyd v. United States, 116 U.S. 616 (1886).

37. Harris v. United States, 331 U.S. 145, 150 (1947) ; United States v. Rabinowitz, 339 U.S. 56, 63 (1950). 
warrants were held valid. But in both cases the searches were incident to lawful arrests, a circumstance which the Court recognizes as a special exception to the general rules governing searches and seizures and which is not present in the ordinary welfare search.

With respect to the reasonableness of a search of a private dwelling, not supported by a lawful arrest, the Supreme Court first stated its position in Agncllo v. United States: $: 38$

While the question has never been directly decided by this court, it has always been assumed that one's house cannot lawfully be searched without a search warrant, except as an incident to a lawful arrest therein .... The protection of the Fourth Amendment extends to all equally,-to those justly suspected or accused, as well as to the innocent. The search of a private dwelling without a warrant is in itself unreasonable and abhorrent to our laws. ... Belief, however well founded, that an article sought is concealed in a dwelling house furnishes no justification for a search of that place without a warrant. And such searches are held unlawful notwithstanding facts unquestionably showing probable cause. ${ }^{30}$

This case is the first of a series in which the Court expressed the view that a private dwelling has a special sanctity. In the case of a home, even if officers have good reason to believe they will find evidence of wrongdoing, it is unreasonable per se for them to enter without first obtaining a warrant. The Court adhered to this strict view in Taylor $v$. United States. ${ }^{40}$

In Johnson v. United States, ${ }^{41}$ the Court had before it a case which on its facts was remarkably similar to the nocturnal calls of welfare investigators. At about 7:30 p.m. an officer of the Seattle police force received information from an informant that persons were smoking opium in the Europe Hotel. The police and narcotics agents, arriving at the hotel, recognized the smell of burning opium, which led them to Room 1 . They knocked, identified themselves as officers, demanded entry, and were admitted. The Supreme Court held that while the search would have been justifiable if made upon a warrant obtained from a judge, since it was in fact made without a warrant it violated the fourth amendment. ${ }^{42}$

In the recent case of Chapman v. United States, ${ }^{43}$ the Court explicitly reaffirmed the views expressed in Agnello, Taylor and Johnson. It then went further and declared that a rented dwelling has the same protection as one that

38. 269 U.S. 20 (1925).

39. Id. at $32-33$.

40. 286 U.S. 1 (1932).

41. 333 U.S. 10 (1948).

42. Crime, even in the privacy of one's own quarters, is, of course, of grave concern to society, and the law allows such crime to be reached on proper showing. The right of officers to thrust themselves into a home is also a grave concern, not only to the individual but to a society which chooses to dwell in reasonable security and frcedom from surveillance. When the right of privacy must reasonably yield to the right of search is, as a rule, to be decided by a judicial officer, not by a policeman or government enforcement agent. Id., at 14.

43. 365 U.S. 610,613 (1961). 
is owned, even if the landlord consents to the officers' search of the tenant's quarters.

The authorities discussed show that inspecting the homes of persons receiving public assistance without warrants is, regardless of variations in circumstances, unreasonable and therefore illegal and unconstitutional. Plainly, no arguments based on necessity to enforce the welfare laws will justify the search without warrants of the homes of welfare recipients. Nor will any amount of information showing the likelihood of violation. On this question, the Supreme Court has been so clear and consistent that further citation of authorities is unnecessary. In sum, midnight welfare searches, as commonly practiced, are a flagrant violation of the fourth and fourteenth amendments.

\section{The Social Security Act and the Responsibility of the Depart- ment of Health, Education and Welfare}

If the practice of searching the homes of public assistance recipients is unconstitutional, why has it continued so long? A major reason is that persons on public assistance are in no position to enforce a constitutional right of privacy. They lack the means and knowledge to litigate constitutional questions. And the available legal remedies are most inadequate. Until 1961 there was, for all practical purposes, no remedy whatever that could be invoked by a private individual whose home had been invaded in violation of the federal Constitution. Since Mapp v. Ohio, ${ }^{44}$ evidence obtained as the result of such an invasion has been inadmissible in a subsequent state criminal trial, and it might also be held inadmissible in a hearing to revoke eligibility for welfare. But these remedies are strictly after-the-fact; they do not bar the searches. The only way to bar the searches is to refuse to admit the investigators, and in the present state of the law that means risking the loss of subsistence for the family.

These circumstances bring into sharp focus the question of national responsibility for the administration of those state programs which receive federal aid under the Social Security Act. Are midnight searches compatible with the Act? And does the Department of Health, Education and Welfare have any power or responsibility with respect to such searches? In the absence of other effective means to enforce the constitutional rights of a large group of the poor and the ignorant, these questions are urgent.

\section{A. Are Illegal Searches Compatible with the Act?}

The Social Security Act provides for federal-state cooperation in welfare programs. The programs are established and administered by state legislatures and state executives. To encourage the establishment of such programs, the federal government offers substantial financial assistance, both for subsistence payments and for administrative expense. To qualify for receipt of these federal funds, however, the state programs must conform to specified federal standards

44. 367 U.S. 643 (1961). 
stated in the Act. Interpretation of these standards, and application of them to state legislation, case-law, and administrative practice is the responsibility of the Secretary of the Department to which the particular program has been assigned-in the case of Dependent Child and similar benefits, the Department of Health, Education and Welfare. On the basis of his periodic certification to the Secretary of the Treasury that a state program is or continues to be in conformity with the federal standards, payments of federal funds are made. If he finds a lack of or departure from conformity, they may be withheld. ${ }^{45}$ It is uncertain whether his determinations are subject to judicial review. ${ }^{\mathbf{4 0}}$

The standards set by Congress include matters of procedure and administration. For example, the federal program of grants to states for aid and service to needy children contains detailed provisions as to how a state plan must be administered, including a requirement of fair hearings on denial of applications, ${ }^{47}$ and safeguards for keeping confidential all information concerning applicants. ${ }^{48}$ It is therefore clear that Congress has asserted the power to control at least some aspects of the administration of state plans, and that Congress has in fact concerned itself with questions of state procedure and administration. Against this background, the issue is whether the constitutional prohibition against searching homes must be recognized as one of the federal standards to which state plans must conform.

The Social Security Act itself does not contain any provisions with respect to search and seizure. This is not surprising; there is nothing about the Social Security Act, as distinguished from many other federal statutes, which would suggest that search and seizure problems might arise under it. But Congress has enacted legislation with respect to searching private homes in connection with the enforcement or administration of any federal statute. Section 2236 of Title 18, U.S.C. provides:

Section 2236. Searches without warrant.

Whoever, being an officer, agent, or employee of the United States or any department or agency thereof, engaged in the enforcement of any law of the United States, searches any private dwelling used and occupied as such dwelling without a warrant directing such search, or maliciously and without reasonable cause searches any other building or property without a search warrant, shall be fined for a first offense not more than $\$ 1,000$; and, for a subsequent offense, shall be fined not more than $\$ 1,000$ or imprisoned not more than one year, or both.... $* * * *$

This statute is unquestionably binding on the Department of Health, Educttion, and Welfare and all of its employees. It also applies to all persons acting as "agents" of the United States, including officers of the District of Columbia.

45. 49 Stat. 628 (1935), 42 U.S.C. $\$ \$ 603-04$ (1958).

46. See Arizona ex rel. State Board of Public Welfare v. Hobby, 221 F.2d 498 (D.C. Cir. 1954); Indiana ex rel. State Board of Public Welfare v. Ewing, 99 F. Supp. 734 (D.D.C. 1951), vacated as moot, 195 F.2d 556 (D.C. Cir. 1952).

47. 49 Stat. 627 (1935), 42 U.S.C. $\S 602$ (a) (4) (1958).

48. 53 Stat. 1380 (1939), 42 U.S.C. $§ 602$ (a) (8) (1958). 
While it is doubtful that a state officer enforcing a federal-state program is an "agent" of the United States, the spirit of the statute is a broad one.40

The fact that Congress dealt explicitly with the search of divellings is of special significance. The protections of the fourth amendment include many matters other than the search of dwellings; arrests, seizures, and searches of places other than homes are covered. But Congress deemed the privacy of homes to be of such importance that it singled out the practice of searching dwellings to declare affirmatively that the enforcement of federal law by use of this practice is a criminal offense.

Congress has sought to ensure that no state welfare program be approved under the Social Security Act unless it meets Congress' standards. It requires little by way of implication to read the Act so as to include, among essential federal standards, a congressional policy against searching dwellings that is so specific in its object and so broad in its applicability. Certainly if a state program expressly listed searches of dwellings among its provisions for administration, it would be highly incongruous to hold such a program to be in compliance with federal standards.

But even if Congress had enacted no statutes dealing with searches by public officials, the Constitution sets its own standards for the administration of federally assisted programs. For example, Congress could not assist a state welfare plan which was administered so as to discriminate against persons because of their race or religion. ${ }^{50}$ Government funds may not be spent in a way that discriminates in violation of the Constitution. ${ }^{51}$ This principle has been asserted in a recent Department of Health, Education and Welfare memorandum holding that a provision of Michigan law limiting benefits available to dependent child beneficiaries was inconsistent with federal standards under the Act. ${ }^{.2}$

The principle is not limited to violation of the Constitution by discrimination. It is equally plain, for example, that the federal government could not spend its money in support of a program that violated the first amendment. The underlying proposition is that Congress may not apply public funds to any plan or program that violates any of the provisions of the Constitution.

49. State officials are subject to an entirely separate federal statute prohibiting them, subject to federal penalty, from enforcing any law, state or federal, by means that deprive people of their constitutional rights. This is the old Civil Rights Statute, 18 U.S.C. § 242 (1958), and at a minimum it shows congressional concern that state officials enforce their laws only by constitutional means.

50. This was recognized by Judge Schweinhaut in Arizona $c x$ rel. State Board of Public Welfare v. Ewing, Administrator of the Federal Social Security Act, Civil No. 2008-52, D.D.C., 1952, aff'd as modified sub nom., Arizona ex rel. State Board of Public Welfare v. Hobby, 221 F.2d 498 (D.C. Cir. 1954).

51. E.g., Burton v. Wilmington Parking Authority, 365 U.S. 715 (1961).

52. Memorandum by Alanson W. Willcox, General Counsel of the Department of Health, Education and Welfare, entitled "Memorandum Concerning Authority of the Secretary, under title IV of the Social Security Act, to Disapprove Michigan House Bill 145 on the Ground of its Limitations on Eligibility." (Mfarch 25, 1963). See also the statement of Secretary Celebrezze on this same subject, dated Mfarch 26, 1963. 


\section{B. The Department's Responsibility}

In light of this principle, and in light of congressional policy on searches of dwellings, what is the power, and the responsibility, of the Secretary of Health, Education and Welfare with respect to a state welfare program administered by illegal inspections of recipients' homes? This question involves the Secretary's power to issue regulations governing federally supported state programs, or to disapprove programs that, in his judgment, do not conform to federal standards.

The Secretary has general power to issue regulations under Section 1102 of the Social Security Act. ${ }^{53}$ With respect to state plans for aid to dependent children, his power is very specific; a state must "provide such methods of administration ... as are found by the Secretary to be necessary for the proper and efficient operation of the plan." 54 The word "proper" should be emphasized. In at least two instances the Secretary has recognized and exercised the power to disapprove state plans on grounds not explicitly set forth in the Social Security Act. $\mathrm{He}$ disapproved plans which deny aid to needy children on the basis of a "suitable home" eligibility condition, ${ }^{, 5}$ and he rejected Michigan House Bill 145 because of arbitrary discrimination in its plan of eligibility.

These powers and precedents seem ample to support a ruling or regulation by the Secretary barring the practice of administering state plans by unconstitutional searches of recipients' homes. In the case of the "suitable home" requirements, cited above, ${ }^{, 7}$ the Secretary disapproved the state programs because they imposed "a condition of eligibility that bears no just relationship to the Aid for Dependent Children program." ${ }^{8}$ For authority the Secretary hat only the general purposes of Title IV of the Social Security Act, and the general principle that it would be unjust to withdraw aid from children because of the nature of the home in which they live. But the Secretary found that, despite the absence of more specific statutory authority, he was responsible to see that federal grants were made only with respect to state programs that carried out the general purposes of the Act. In the case of Michigan House Bill 145, also cited above, the Secretary reasserted the authority to disapprove programs on general grounds, and the general counsel said that the Secretary could unquestionably disapprove a program which appeared unconstitutional. He said: "It would appear self-evident that the Secretary might properly disapprove a state plan so discriminatory as to be unconstitutional under the Fourteenth Amencl-

53. 49 Stat. 647 (1935), 42 U.S.C. § 1302 (1958).

54. 53 Stat. 1379 (1939), 42 U.S.C. $\$ 602$ (a) (5) (1958).

55. Memorandum for The Commissioner of Social Security from Secretary Flemming, January 16, 1961.

56. Statement of Secretary Celebrezze, March 26, 1963 (disapproving Michigan House Bill 145 because of arbitrary discrimination:).

57. 49 Stat. 627 (1935), 42 U.S.C. $\$ 602$ (a) (4) (1958).

58. Memorandum for The Commissioner of Social Security from Secretary Flemming, supra note 57 , at 2 . 
ment." 59 It follows that the Secretary can also disapprove a plan that is unconstitutional under the fourth and fourteenth amendments.

If the Secretary has the power, what is his responsibility and duty? The Supreme Court has suggested an answer in an analogous situation. A state provided financial aid to a private restaurant. It had the power to prohibit racial discrimination by the restaurant as a condition of supplying the assistance, but it failed to exercise this power. The Court said, in words that apply forcefully to the Department of Health, Educattion and Welfare in the present situation:

As the Chancellor pointed out, in its lease with Eagle the Authority could have affirmatively required Eagle to discharge the responsibilities under the Fourteenth Amendment imposed upon the private enterprise as a consequence of state participation. But no State may effectively abdicate its responsibilities by either ignoring them or by merely failing to discharge them whatever the motive may be. . . . By its inaction, the Authority, and through it the State, has not only made itself a party to the refusal of service, but has elected to place its power, property and prestige behind the admitted discrimination. ${ }^{60}$

Thus if the Secretary permits federal funds to be dispensed to states which use administrative methods that violate the Constitution, he permits the "power, property and prestige" of the federal government to support such practicespractices which cannot effectively be contested by the unfortunate victims. In such circumstances, the Secretary's duty to exercise his power by prohibiting the unconstitutional practices seems both plain and unavoidable. Here, as in the case of racial discrimination, there is evidence of the increasing need for government to intervene affirmatively if rights guaranteed by the Constitution are to be secured in fact.

\section{A Further QUESTION}

Social security and public assistance are the heart of the welfare state. They recognize that in a complex industrial society individuals cannot always be "blamed" for inability to support themselves, and that responsibility for individual subsistence must be widely shared. But must the price of state support be the erosion of self-respect, and individual rights against government?

Welfare implies dependence. And dependence means that people may more easily be induced to part with rights which they would ordinarily defend. A not uncommon psychology leads those who dispense welfare to feel it only just that the beneficiaries give up something in return. To some public officials, opening one's home to inspection evidently seems a reasonable condition to impose on those whose homes are supported by a public agency. In many other ways, subtle and obvious, the recipients of public bounty are made to pay a similar price. They may be asked to observe standards of morality not imposed on the rest of the community. They may be forced to endure official condescension and prying.

59. Statement of Secretary Celebrezze, supra note 56, at 2 n.1.

60. Burton v. Wilmington Parking Authority, 365 U.S. 715, 725 (1961). 
If the welfare state is to be faithful to American traditions, government must recognize its duty, even as it hands out benefits, to preserve the independence of those it helps. In a complex society, individual rights are as much a community responsibility as food and clothing.

It is most unfortunate that the Social Security Act should have become a means, however indirect, for depriving some persons of the privacy guaranteed by the fourth amendment. The chief object of the amendment was to protect the home and, thereby, the integrity of every individual. The object of the Social Security Act was also to protect the home, and to protect independence and self-respect. It undoes the most fundamental purpose of the Act if it is enforced by methods that violate the sanctity of the home and degrade and humiliate recipients. To insist that welfare officials obey the fourth amendment is no more than to insist that the high aim of the Social Security Act not be forgotten in the day-to-day difficulties of carrying it out; and to make certain that the Act remains what it was, above all, intended to be-a guardian and insurer of the dignity of man. 


\section{THE YALE LAW JOURNAL}

\begin{tabular}{lll}
\hline VoluMe 72 & JUNE 1963 & NUMBER 7 \\
\hline
\end{tabular}

ROBert A. Burt

JoHN A. KoskINEN

EuLtotT J. WetsS

WIIITAM C. WhITFORd

Note \& Comment

Editors

Barbara A. Babcock

EDWARD L. BarLOW

Donaid C. Christ

JOSEPH D. CIAYTON

EDWard R. CoHEN

THEODORE B. DonsoN

Margaret F. Ewing

STEPHEN R. FIELD

AsHLEY L. ForD

JOSEPE W. GELB
Peter L. Strauss

Editor-in-Chief

Monroe E. Price

Executive Editor

Thonsas K. Grimoor

Paut Grossarast

Charles R. Halpern

JoHN D. Hoffasan

Mitchaed J. HoRowitz

ALIEN I. IsaACSON

ALAN D. JACOBSON

Howard J. KasLow

RrCeARD A. Katzive

ANthony S. Kolker

JoHN L. KRAFT
Robert E. Cooper

Steven Al. Uams Article \& Bools Reviezu Edilors

ROGER W. TOSPSINS MFanaging Editor

MLARTIN LEVTAE JOBN J. AfCATEE, JR. Josepr D. MANNDEL. ARTHUR A. MlUmisterr Jasies J. MIURRay Robert E. PhaY Rozert B. Schyemen G. Pearson Simti, Jr. WaRREN G. Wickirsenas Jore A. Young

Marte micManon

Business Secretary

The Journal membership expresses its appreciation to the outgoing Board of Officers and announces the election of the new Board.

\section{CONTRIBUTORS TO THIS ISSUE}

Eugene V. Rostow. B.A. 1933; M.A. 1937; LL.B. 1937, Yale University; Dean of the Law School.

Daniel John Meador. B.S. 1949, Auburn University; LL.B. 1951, University of Alnbama; LL.M. 1954, Harvard University.

Bernetard Grossfeld. Oberschule Nordhorn, Abitur, 1954; Freiberg 1/54-2/55; Hamburg University 1/55-2/56; LL.M. 1963, Yale University.

Charles A. Reich. B.A. 1949, Oberlin; LL.B. 1952, Yale University.

WARd S. Bowman, JR. B.A. 1933; M.A. 1935, University of Washington.

KAzIMIERz GrzYBowskr. LL.MI. 1929; Dr.Jur. 1934, University of Lwow; J.S.D. 1932, Harvard University. 